Cite this: Phys. Chem. Chem. Phys., 2012, 14, 3681-3692

\title{
Influence of polystyrenesulfonate on electron transfer quenching of ruthenium trisbipyridine luminescence by viologens: non-covalent assembly and covalent tethering of the ruthenium complex $\dagger$
}

\author{
Eimer M. Tuite, ${ }^{* a}$ David B. Rose, ${ }^{a}$ Patricia M. Ennis ${ }^{b}$ and John M. Kelly ${ }^{c}$ \\ Received 15th November 2011, Accepted 11th January 2012 \\ DOI: $10.1039 / \mathrm{c} 2 \mathrm{cp} 23597 \mathrm{~h}$
}

A new copolymer (RuB-PSS) of ruthenium(II)bis-(2,2'-bipyridine)(4-vinyl 2,2'-bipyridine) and styrene sulfonate was prepared which tethers the ruthenium chromophore directly to the polymer backbone. The photophysical properties of the copolymer, and its luminescence quenching by viologens, were compared with those of ruthenium(II)tris-bipyridine, $\left[\mathrm{Ru}(\mathrm{bpy})_{3}\right]^{2+}$, bound non-covalently to polystyrenesulfonate (PSS) via hydrophobic and electrostatic interactions. Enhancement of ruthenium polypyridyl complex luminescence in both systems is due to decreased rates of non-radiative decay when removed from bulk water as well as reduced oxygen quenching. Molecular dynamics simulations show an open PSS chain conformation with induction of local curvature around the ruthenium centres. Hence, the complexes remain exposed to water, albeit less so than in bulk solution, as evidenced by low enhancement of bound $\left[\mathrm{Ru}(\mathrm{phen})_{2} \mathrm{dppz}\right]^{2+}$ emission. Quenching by $\mathrm{O}_{2}$ is hindered for both systems due to combined polarity, ionic strength, and viscosimetric effects that influence local concentrations and diffusion of reactants. Electron transfer quenching of the Ru centre by zwitterionic propyl viologen sulfonate $\left(\mathrm{PVS}^{0}\right)$ and cationic methyl viologen $\left(\mathrm{MV}^{2+}\right)$ is enhanced for $\left[\mathrm{Ru}(\mathrm{bpy})_{3}\right]^{2+} / \mathrm{PSS}$, but retarded for RuB-PSS, despite the attraction of the quenchers for PSS. PSS binding hinders separation of the electron transfer products relative to aqueous solution, excepting an increase for RuB-PSS $/ \mathrm{PVS}^{0}$. We conclude that anionic hydrophobic polymers such as PSS can differentially influence forward- and reverse- electron transfer reactions depending on the charge and hydrophobicity of the reactants. In the context of small molecule binding, we find that PSS provides a tenable model for DNA.

\section{Introduction}

Photochemistry of reactants assembled in interfacial systems such as micelles, microemulsions, zeolites, ion-exchange resins, polymers and polyelectrolyte solutions are of interest from a number of perspectives; as mimics of biological processes, for photochemical energy conversion and storage systems, and in probing of the microenvironment. ${ }^{1,2}$

\footnotetext{
${ }^{a}$ School of Chemistry and Chemical nanoscience Laboratory,

Bedson Building, University of Newcastle, Newcastle upon Tyne,

NE17RU,England.E-mail: eimer.tuite@ncl.ac.uk;

Fax: + 44191222 6929; Tel: + 441912225523

${ }^{b}$ School of Chemical and Pharmaceutical Sciences,

Dublin Institute of Technology, Kevin Street, Dublin 8, Ireland.

E-mail:patricia.ennis@dit.ie

${ }^{c}$ School of Chemistry and Centre for Chemical Synthesis and

Chemical Biology, Trinity College, Dublin 2, Ireland.

E-mail:jmkelly@tcd.ie

$\dagger$ Electronic supplementary information (ESI) available: Additional data; information regarding $\mathrm{MM} / \mathrm{MD}$ calculation parameters and images; calculation of diffusion-controlled rate constants. See DOI: $10.1039 / \mathrm{c} 2 \mathrm{cp} 23597 \mathrm{~h}$
}

Anionic polyelectrolytes comprise one class of interfacial system which has attracted the attention of photochemists as media which affect photochemical reactions and which may be used to inhibit back-electron-transfer reactions. Examples of polyanions studied in this context include polystyrenesulfonate (PSS), polyvinylsulfate (PES) and polyacrylic acid (PAA), in addition to biopolymers such as proteins and nucleic acids. PSS is one of the simplest polyelectrolytes which has been shown to possess hydrophobic properties. ${ }^{3,4}$ As such, it can be used as a simple model for biomacromolecules such as nucleic acids, as it allows the combined effects of hydrophobic and electrostatic interactions to be explored at a basic level, without the complications introduced by the diverse potential binding modes for small molecules with DNA (intercalation, minor groove binding, etc. ${ }^{5}$ ). The polymer dynamics of PSS and DNA have been compared previously, ${ }^{6,7}$ so variation of their effects on reactivity can be compared systematically. Comparative effects of PSS and DNA on photoinduced electron transfer reactions have been reported previously ${ }^{8,9}$ and recently the interactions of PSS and DNA 

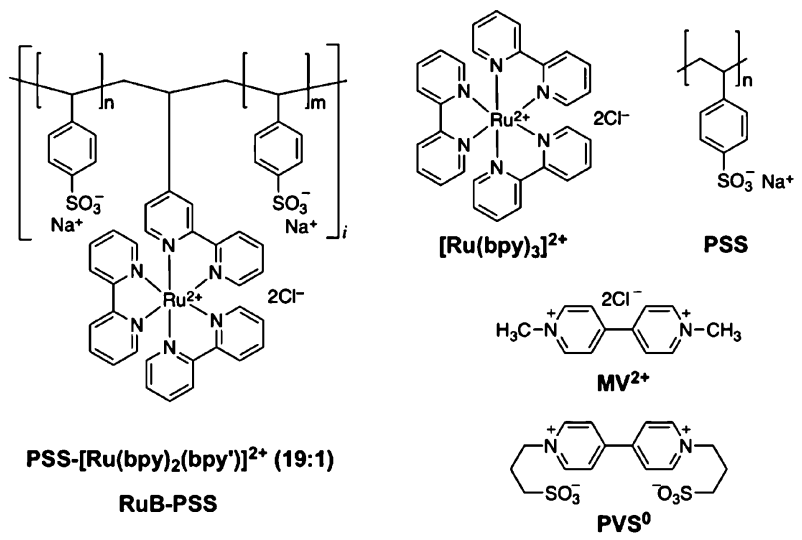

Fig. 1 Structures of the compounds examined in this study (see footnotes for abbreviations).

with quantum dots have been compared in a single molecule microscopy study. ${ }^{10}$

It has been suggested that directional electron transfer along DNA occurs when migrating radicals are created in the nucleic acid, and this remains an area of intense research effort. ${ }^{11}$ In many cases of fast electron transfer between molecules bound to DNA, this is due to the effect of concentrating the reactants in the polyelectrolyte field of DNA. ${ }^{8,12,13}$ However, fast electron transfer between intercalators at defined separations can also occur. ${ }^{14-17}$ To fully understand our work on electron transfer quenching of ruthenium complexes bound to DNA, ${ }^{18}$ we have examined the quenching of a ruthenium polypyridyl complex by two viologens in the presence of PSS (Fig. 1). The interactions of both fluorophore and quenchers with the polyelectrolyte should be electrostatic and hydrophobic but with no specific binding modes possible compared to DNA.

Ruthenium polypyridyl complexes possess excitation and emission characteristics that vary considerably with their environment, and have been well-characterised in numerous studies over several decades. ${ }^{19-21}$

The simplest complex of the class is ruthenium(II)tris(2,2'bipyridine) - $\left[\mathrm{Ru}(\mathrm{bpy})_{3}\right]^{2+}$ (Fig. 1) - where the lowest excited state is ${ }^{3}$ MLCT in character. This state undergoes relatively slow radiationless transitions to the ground state, and exhibits a long emission lifetime and significant luminescence $\left(\Phi_{\mathrm{f}}=\right.$ 0.040 in aerated $\mathrm{H}_{2} \mathrm{O}^{22}$ ). Aspects of the binding of this and related complexes to PSS in solution have been investigated previously, ${ }^{8,9,23-29}$ and have demonstrated concerted electrostatic and hydrophobic interactions. Binding constants are reported of $1.1 \times 10^{4} \mathrm{M}^{-1}$ for $\left[\mathrm{Ru}(\mathrm{bpy})_{3}\right]^{2+} / \mathrm{PSS}$ and $3.6 \times 10^{4} \mathrm{M}^{-1}$ for $\left[\mathrm{Ru}(\text { phen })_{3}\right]^{2+} / \mathrm{PSS}$, both in $100 \mathrm{mM} \mathrm{NaCl}{ }^{29}$

The ${ }^{3} \mathrm{MLCT}$ state of $\left[\mathrm{Ru}(\mathrm{bpy})_{3}\right]^{2+}$ possesses suitable properties to play the role of energy donor, electron donor, or electron acceptor, depending on the properties of the quencher molecule. Oxidative quenching of ${ }^{3}\left[\mathrm{Ru}(\mathrm{bpy})_{3}\right]^{2+}$ by viologens, especially methyl viologen $\left(\mathrm{MV}^{2+}\right)$, has been well characterised in solution $^{30,31}$ and is often used as a standard system to investigate the effect of the microenvironment on electron transfer reactions. ${ }^{2}$ In this study, we examine the ${ }^{3}\left[\mathrm{Ru}(\mathrm{bpy})_{3}\right]^{2+} / \mathrm{MV}^{2+}$ electron donor/acceptor system in a PSS environment, where the cationic quencher and its reduced product are attracted to the polyanion, and compare it with the behaviour of the ${ }^{3}\left[\mathrm{Ru}(\mathrm{bpy})_{3}\right]^{2+} / \mathrm{O}_{2}$ and
${ }^{3}\left[\mathrm{Ru}(\mathrm{bpy})_{3}\right]^{2+} / \mathrm{PVS}^{0}\left(\mathrm{PVS}^{0}=\right.$ propyl viologen sulfonate $)$ systems, where the quenchers are formally neutral and do not bind electrostatically to PSS, although hydrophobic effects may lead to interactions. The effect of PSS on recombination reactions was a key consideration of this study, as it was anticipated that negatively charged reaction products would be repelled from the polyanion leading to improved cage escape yields.

In addition to studying $\left[\mathrm{Ru}(\mathrm{bpy})_{3}\right]^{2+}$, we also covalently attached the ruthenium chromophore to the PSS backbone by preparing a novel copolymer, RuB-PSS (19:1 [sodium polystyrenesulfonate]-[Ru(bpy $\left.)_{2}\left(\mathrm{bpy}^{\prime}\right)\right]^{2+}$ copolymer, where bpy $^{\prime}=4$-vinyl-2,2'-bipyridine). This copolymer eliminates effects of chromophore diffusion and displacement from the polyelectrolyte.

\section{Experimental}

\section{Chemicals}

Sodium chloride (Reidel de Haan, 99.8\%) and magnesium chloride (M\&B, 97\%) were recrystallised before use. All solvents were of the highest available commercial grade and were purified by distillation when required. Singly distilled water was deionised in a Millipore Milli-Q water purification system.

$\mathrm{Ru}(\mathrm{bpy})_{3} \mathrm{Cl}_{2} \cdot 6 \mathrm{H}_{2} \mathrm{O}$ was synthesised by the method of Braddock and Meyer $^{32}$ and purified on Sephadex LH-20 with methanol elution. The $\left[\mathrm{Ru}(\mathrm{bpy})_{3}\right]^{2+}$ concentration was determined using $\varepsilon_{452}=14600 \mathrm{M}^{-1} \mathrm{~cm}^{-1} .33$

Samples of NaPSS (206.19 $\mathrm{g} \mathrm{mol}^{-1}$ per ethylstyrenesulfonate repeat unit) from Polysciences Inc. had molecular weights of 50000 (243 repeat units; PI 3-5) and 500000 (2425 repeat units; PI 3-30), and were used without further purification. The concentration of the polymer is given as the concentration of the sulfonate units. Both samples of PSS gave comparable results, as reported previously by others ${ }^{26}$ and PSS of molecular weight 50000 was used throughout.

Methyl viologen dichloride dihydrate $(98 \%)$ was purchased from Aldrich and used without further purification.

Propyl viologen sulfonate was synthesised by stirring a mixture of 1,3-propane sultone (Aldrich, 97\%) and 4,4'-bipyridine $(\mathrm{BDH}, 99 \%)$ in methanol at room temperature for $12 \mathrm{~h}$ according to the procedure of Nagamura et al. ${ }^{34}$ The crude product was collected and assessed by tlc (silica, $\mathrm{AcOH} / \mathrm{MeOH}$, $9: 1)$. The product was precipitated from water with methanol three times and the white solid obtained was vacuum dried.

A novel copolymer of $\left[\mathrm{Ru}(\mathrm{bpy})_{2} \text { (4-vinyl-bpy) }\right]^{2+}$ and sodium styrene sulfonate was prepared by the vinyl polymerization method of Taguchi et al. ${ }^{35}$ using a $\mathrm{SS} / \mathrm{Ru}$ reaction ratio of $10: 1$. An azobisisobutyronitrile (AIBN) radical initiator was used with a $\beta$-cyclodextrin $(\beta-C D)$ carrier in a two phase system of water and an organic solvent (chloroform/petrol ether, $1: 4$ ). The sample was purified by multiple precipitations from water with acetone, then dialysed against sodium chloride solution and subsequently against deionised water. However, it proved impossible to remove $\beta-C D$ from the polymer and an SS:CD ratio of $1: 0.8$ was determined by ${ }^{1} \mathrm{H}-\mathrm{NMR}$ in $\mathrm{D}_{2} \mathrm{O}$. This suggests inclusion of the monomer units within the $\beta-C D$ cavity during polymerisation. Analysis of ruthenium by atomic absorption and sodium by flame photometry 
(taking account of the residual $\beta-\mathrm{CD}$ ) yielded an approximate loading of $19 / 1(\mathrm{SS} / \mathrm{Ru})$ in the copolymer. Terminal polymer protons had detectable $\mathrm{nmr}$ signals, indicating that the copolymer chains are relatively short.

\section{Control of oxygen concentration in solution}

Deoxygenated solutions were obtained by bubbling with $\mathrm{H}_{2} \mathrm{O}$ saturated argon for at least $1 \mathrm{~h}$. This procedure gave results comparable with four-cycle freeze-pump-thaw degassing under high vacuum. Oxygen saturated solutions were flushed with $\mathrm{H}_{2} \mathrm{O}$-saturated $\mathrm{O}_{2}$ for at least $30 \mathrm{~min}$.

\section{Instruments}

All experiments were thermostatted at $25^{\circ} \mathrm{C}$. Absorption spectra were recorded on a Pye-Unicam PU-880 UV/vis spectrometer.

Steady state emission and excitation spectra were recorded using a Perkin-Elmer MPF-44B spectrofluorimeter, with a $150 \mathrm{~W}$ Xe source and a Hamamatsu R928 red-sensitive photomultiplier.

Emission lifetimes were determined by time-correlated single photon counting on an Edinburgh Instruments FL-900 Fluorescence Lifetime Spectrometer. The excitation source was a coaxial nanosecond flashlamp which delivered nanosecond pulses with a repetition rate of $6.3 \mathrm{kHz}$ at $358 \mathrm{~nm}\left(\mathrm{~N}_{2}\right)$, minimum pulse width of $1.2 \mathrm{~ns}$, and an intensity of $10^{10}$ photons/pulse.

Nanosecond flash photolysis experiments were performed using a Lambda Physik EMG $50 \mathrm{XeCl}$ excimer laser (308 nm; pulse energy $\sim 25 \mathrm{~mJ}$; pulse length $\sim 15 \mathrm{~ns}$ ) to pump an Oxford Instruments EDL1 dye laser containing Coumarin 120 (Lambdachrome from Lambda Physik) in methanol (441 nm; pulse energy $\sim 2.5 \mathrm{~mJ}$ ). The signal was monitored using an Applied Photophysics Laser Kinetic Spectrophotometer with a water-cooled $250 \mathrm{~W}$ xenon short-arc lamp source.

\section{Molecular dynamics simulations}

Molecular modelling (MM) and molecular dynamics (MD) simulations were carried out within Material Studio 4.3 (Accelrys). MM/MD simulations were performed for dilute isotactic chains of (i) poly-sodium- $p$-styrenesulfonate (PSS), (ii) PSS with two sodiums in a $20 \mathrm{mer}$ repeat replaced by $\left[\mathrm{Ru}(\mathrm{bpy})_{3}\right]^{2+}$, and (iii) poly-sodium- $p$-styrenesulfonate-costyrylbipyridine-ruthenium(II)bipyridine dichloride (19:1), with degrees of polymerization $N=20,40,60$, and 100 . The basic repeat unit for the calculations was a $20 \mathrm{mer}$, and calculations were performed with a ruthenium complex attached, either covalently or non-covalently, at the end or centre of the repeat unit. For each polymer, the calculation was carried out in four steps (full details in ESI), with a check between each step that the system remained overall charge neutral: (i) Forcite geometry optimisation, using the universal force-field; (ii) Discover Minimisation, using compass (for PSS) or esff (for systems containing Ru) force fields; (iii) Discover Dynamics quick calculation for 5 ps; (iv) Discover Dynamics longer calculation for $50 \mathrm{ps}$.

Two sets of simulations were performed for 20mer polymers; with and without explicit solvent (water). For MD simulations in a dielectric continuum, a relative permittivity of 77.73 was used, corresponding to water at $300 \mathrm{~K} .{ }^{36}$ No significant difference was found between the polymer conformations obtained by different methods for solvent modelling, and a dielectric continuum was used for the majority of the calculations.

\section{Results and discussion}

\section{Synthesis of RuB-PSS}

To understand fully the photophysics of ruthenium complexes when they are bound within the PSS environment, we have synthesised a copolymer in which an $\left[\mathrm{Ru}(\mathrm{bpy})_{3}\right]^{2+}$ analogue is directly bonded to the backbone, RuB-PSS. A number of polymerization methods to incorporate the ruthenium chromophore into the polystyrenesulfonate chain were attempted, including those used previously to synthesise copolymers with vinyl-pyridine, ${ }^{37,38}$ the most successful was that described in the experimental section. In the copolymer, one of the bipyridine ligands is attached directly to the polyelectrolyte backbone, so the ruthenium centre is as close as possible to the anionic sulfonate groups, while the tethered ligand is surrounded by aromatic phenyl groups. This environment is designed to approximate that envisaged for $\left[\mathrm{Ru}(\mathrm{bpy})_{3}\right]^{2+}$ interacting non-covalently with PSS. Unfortunately, $\beta$-cyclodextrin $(\beta-C D)$ used to solubilise the initiator could not be fully removed from the copolymer product, and probably encapsulated the aromatic regions of about $80 \%$ of the styrenesulphonate residues, with the charged groups protruding; a similar result was observed when PSS was synthesised by this method. This would result in increased steric hindrance between polymer residues, potentially restricting accessible polymer conformations, but would not affect the electrostatics or the spatial arrangement of hydrophilic and hydrophobic regions. Addition of $\beta-C D$ to solutions of $\left[\mathrm{Ru}(\mathrm{bpy})_{3}\right]^{2+}$ with PSS at PSS $/ \mathrm{Ru}>25$ had no effect on emission intensity, indicating that neither $\beta$-CD nor its interaction with PSS significantly affects the photophysics of the bound complex. Hence, despite the presence of $\beta-\mathrm{CD}, \mathrm{RuB}-\mathrm{PSS}$ provides a reasonable comparison with the non-covalent complex. in terms of photophysics and binding.

\section{The effect of PSS on the absorption and emission spectra of $\left[\operatorname{Ru}(\mathrm{bpy})_{3}\right]^{2+}$ and RuB-PSS}

The effect of added PSS on the absorption and emission spectra of $\left[\mathrm{Ru}(\mathrm{bpy})_{3}\right]^{2+}$ and related ruthenium complexes have been reported previously. ${ }^{24,25,27,29}$ Our results are consistent with previous observations of $2-3 \mathrm{~nm}$ red-shifts and small shape changes in the absorption and luminescence spectra, together with significant changes in luminescence intensity. Comparable changes are observed for the covalently-bound complex in RuB-PSS (Table S1).

The similarity of the absorption and emission spectra in the absence or presence of PSS, or with covalent tethering, indicates that the energy levels of the $\left[\mathrm{Ru}(\mathrm{bpy})_{3}\right]^{2+}$ are only slightly perturbed by the polyelectrolyte environment. No differences in the absorption or emission spectra of $\left[\mathrm{Ru}(\mathrm{bpy})_{3}\right]^{2+}$ were observed in the presence of $\mathrm{PES}^{26,39}$ which has similar linear charge density. This comparison illustrates the importance of hydrophobic interactions between the bipyridine ligands and the nonpolar regions of PSS. 


\section{Emission intensity and lifetime enhancement}

Fig. 2 shows the steady-state luminescence and lifetime enhancements for $\left[\mathrm{Ru}(\mathrm{bpy})_{3}\right]^{2+}$ as PSS is added to aqueous solutions in air. Greater enhancements are observed with more hydrophobic ligands such as phen, dmb, and dip (ESI, Fig. S2). ${ }^{27,29}$ We also observed modest luminescence enhancement on adding PSS to the hydrophobic $\left[\mathrm{Ru}(\mathrm{phen})_{2}(\mathrm{dppz})\right]^{2+}(\mathrm{dppz}=$ dipyrido[2,3-a:3',2'-c]phenazine) (ESI, Fig. S3), which is non-emissive in water and is the archetypal "light-switch" complex for non-aqueous environments, ${ }^{40}$ such as DNA intercalation sites.

For $\left[\mathrm{Ru}(\mathrm{bpy})_{3}\right]^{2+}$ in the presence of PSS, emission decays were mono-exponential for PSS/Ru $>20$, and bi-exponential for $\mathrm{PSS} / \mathrm{Ru}<20$ (Table 1). Average lifetimes for PSS $/ \mathrm{Ru}<20$ were calculated as: ${ }^{41}$

$$
\tau_{\mathrm{av}}=\left(\alpha_{1} \tau_{1}^{2}+\alpha_{2} \tau_{2}^{2}\right) /\left(\alpha_{1} \tau_{1}+\alpha_{2} \tau_{2}\right)
$$

where $\alpha_{\mathrm{i}}$ is the pre-exponential factor for the decay component with lifetime $\tau_{\mathrm{i}}$.

The two decays at PSS $/ \mathrm{Ru}<20$ are attributed to bound and unbound complex, with slow exchange between the two environments. The shorter lifetime correlates with that of free complex (observed at PSS $/ \mathrm{Ru}=0$ ), and the longer lifetime with that at PSS $/ \mathrm{Ru} \geq 50$, where all the complex is bound. The proportion of the longer lifetime increases as PSS is added to the complex. Duveneck et al. ${ }^{27}$ reported similar behaviour previously for $\left[\mathrm{Ru}(\mathrm{phen})_{3}\right]^{2+}$ with PSS (although only single

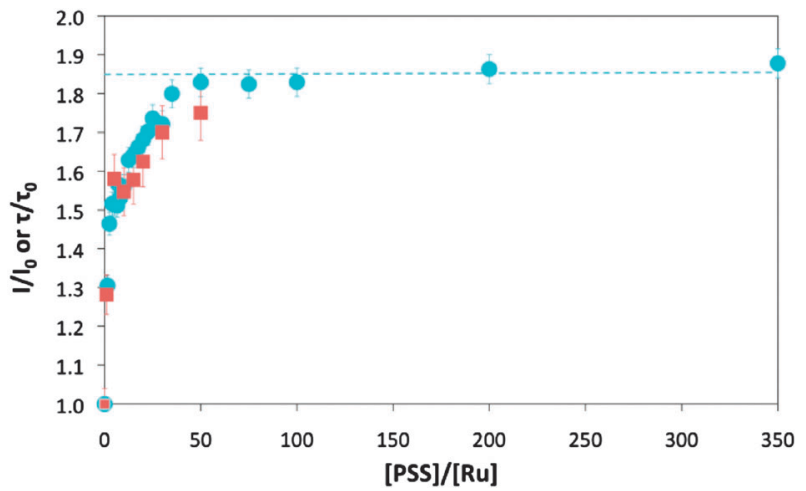

Fig. 2 Increase in the luminescence intensity ( $I, \bigcirc)$ and average lifetime $\left(\tau_{\text {ave }}, \square\right)$ of $\left[\mathrm{Ru}(\mathrm{bpy})_{3}\right]^{2+}$ on addition of PSS to aqueous solution in air. $I_{0}$ and $\tau_{0}$ are the intensity and lifetime in the absence of PSS. $\left[\left[\mathrm{Ru}(\mathrm{bpy})_{3}\right]^{2+}\right]=2 \times 10^{-5} \mathrm{M}$. $\lambda_{\mathrm{ex}}=465 \mathrm{~nm}$ (isosbestic point).

Table 1 Lifetimes $(\tau)$ and pre-exponential factors $(\alpha)$ for double exponential decays of $*\left[\mathrm{Ru}(\mathrm{bpy})_{3}\right]^{2+}$ in the presence of PSS in water under aerated conditions

\begin{tabular}{lccccc}
\hline$[\mathrm{PSS}] / \mathrm{mM}$ & $\mathrm{PSS} / \mathrm{Ru}$ & $\tau_{1} / \mathrm{ns}$ & $\alpha_{1} / \%$ & $\tau_{2} / \mathrm{ns}$ & $\alpha_{2} / \%$ \\
\hline 0.00 & 0 & 360 & 100 & - & - \\
0.02 & 1 & 375 & 68 & 580 & 32 \\
0.10 & 5 & 352 & 14 & 590 & 86 \\
0.20 & 10 & 339 & 11 & 573 & 89 \\
0.30 & 15 & 320 & 8 & 580 & 92 \\
0.40 & 20 & - & - & 612 & 100 \\
1.00 & 50 & - & - & 630 & 100 \\
$\mathrm{RuB}-\mathrm{PSS}$ & 19 & - & - & 540 & - \\
{$\left[\left[\mathrm{Ru}(\mathrm{bpy})_{3}\right]^{2+}\right]$} & $=2 \times 10^{-5} \mathrm{M}$. & & & \\
\end{tabular}

exponential decays were observed for $\left.\left[\mathrm{Ru}(\mathrm{bpy})_{3}\right]^{2+}\right)$. They attributed the two decays to the chromophore residing in different polymer environments such as extended vs. coiled forms, ${ }^{27}$ or hydrophobic interior $v s$. aqueous exterior. ${ }^{9}$ We likewise observed double-exponential emission decays at all $\mathrm{PSS} / \mathrm{Ru}$ ratios for the more hydrophobic complexes $\left[\mathrm{Ru}(\mathrm{phen})_{3}\right]^{2+}$ and $\left[\mathrm{Ru}(\mathrm{phen})(\mathrm{dmb})_{2}\right]^{2+}\left(\right.$ ESI, Table S2). $\left[\mathrm{Ru}(\mathrm{bpy})_{3}\right]^{2+}$, by contrast, appears to bind in a single site; or, if there are multiple sites, they have very similar microenvironments.

The increases in luminescence intensity and lifetime observed when $\left[\mathrm{Ru}(\mathrm{bpy})_{3}\right]^{2+}$ interacts with $\mathrm{PSS}^{24,25,27}$ are attributed to binding in a less polar environment via a combination of electrostatic and hydrophobic interactions, lower local water activity, and reduced oxygen quenching (see below). Shielding $\left[\mathrm{Ru}(\mathrm{bpy})_{3}\right]^{2+}$ from water enhances the luminescence quantum yield, ${ }^{42}$ since the presence of water increases non-radiative decay. ${ }^{43}$ Therefore, localization of the complex in a hydrophobic, water-excluding PSS environment is consistent with the observed increase in emission intensity and lifetime, as well as with the red-shifts of both MLCT absorption and emission maxima. In parallel studies, we have observed that $\left[\mathrm{Ru}(\mathrm{phen})_{2} \mathrm{dppz}\right]^{2+}$ emission is "turned on" when bound to PSS, to almost the same extent as when bound to singlestranded polynucleotide [poly $(\mathrm{dA})]$ at low ionic strength (ESI, Fig. S3). This is consistent with a low polarity and low water activity environment, but the modest light-switch intensity compared to intercalation with ds-DNA ${ }^{44}$ suggests that water is not completely excluded from this hydrophobic microenvironment.

The increase of intensity as more polyelectrolyte is added to the chromophore maximizes at about $\mathrm{PSS} / \mathrm{Ru}=50$ for $\left[\mathrm{Ru}(\mathrm{bpy})_{3}\right]^{2+}$, but not until about PSS/Ru $=200$ for $\left[\mathrm{Ru}(\mathrm{phen})_{3}\right]^{2+}(\mathrm{ESI}, \mathrm{Fig}$. S2), despite the fact that the latter complex binds more strongly. This is consistent with shifting of $\left[\mathrm{Ru}(\mathrm{phen})_{3}\right]^{2+}$ between different binding sites as suggested by Duveneck. ${ }^{27}$ Saturation of the $\left[\mathrm{Ru}(\mathrm{bpy})_{3}\right]^{2+}$ luminescence at $\mathrm{PSS} / \mathrm{Ru} \approx 50$ is consistent with Miyashita et $a{ }^{28}$ who estimated a binding domain of 43 PSS monomers per $\left[\mathrm{Ru}(\mathrm{bpy})_{3}\right]^{2+}$, irrespective of salt concentration or polymer MW.

\section{Effect of oxygen on enhancement of emission}

Fig. 3 illustrates how dissolved oxygen in aqueous solution affects the enhancement of $\left[\mathrm{Ru}(\mathrm{bpy})_{3}\right]^{2+}$ luminescence in the presence of PSS. The emission intensity increases to a maximum relative value of 1.85 in air, 1.3 for argon saturation, and 2.5 for oxygen saturation. The intensity enhancement in argon is attributed exclusively to reduced non-radiative decay of the complex in a hydrophobic PSS microenvironment. The extra enhancements observed in air and oxygenated conditions are attributed to reduced quenching by oxygen in the presence of the polyelectrolyte.

For RuB-PSS, the enhancement in air is 1.6 (vs. 1.85 for fully bound $\left[\mathrm{Ru}(\mathrm{bpy})_{3}\right]^{2+}$ ) and that in argon is 1.15 (vs. 1.3). The similar enhancements compared to noncovalently bound $\left[\mathrm{Ru}(\mathrm{bpy})_{3}\right]^{2+}$ indicate that the covalently tethered complex experiences a similar environment to $\left[\mathrm{Ru}(\mathrm{bpy})_{3}\right]^{2+}$. 


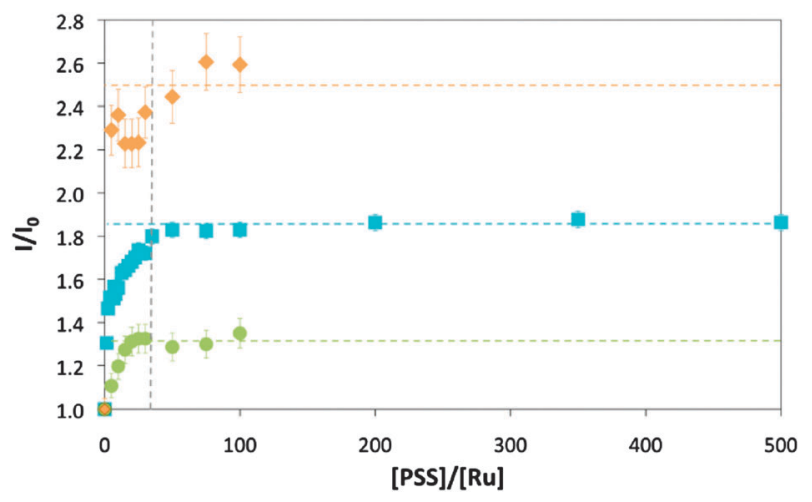

Fig. 3 Increase in the luminescence intensity of $\left[\mathrm{Ru}(\mathrm{bpy})_{3}\right]^{2+}$ on addition of PSS, in deoxygenated $(\diamond)$, aerated $(\odot)$, and oxygensaturated ( $\square$ ) aqueous solution. $\mathrm{I}_{0}$ is the intensity in the absence of PSS. $\left[\left[\mathrm{Ru}(\mathrm{bpy})_{3}\right]^{2+}\right]=2 \times 10^{-5} \mathrm{M}$. $\lambda_{\mathrm{ex}}=465 \mathrm{~nm}$ (isosbestic point).

$\mathrm{O}_{2}$ quenching can be analysed with the Stern-Volmer eqn (2),

$$
\frac{I_{0}}{I}=\frac{\tau_{0}}{\tau}=1+k_{q} \tau_{0}[Q]
$$

where $Q$ is the quencher molecule. A plot of relative intensity, $I_{0} / I$, or lifetime, $\tau_{0} / \tau$, (where zero indicates the value at $[Q]=0$ ) against $[Q]$ yields a quenching rate constant, $k_{q}$ if $\tau_{0}$ is known. If the data from intensity and lifetime are identical, quenching is dynamic. If not, static quenching mechanisms are implicated; most commonly resulting from close association of reactants in the ground state. Comparison of $k_{q}$ with the calculated diffusion-controlled rate constant indicates whether the quenching reaction is activation- or diffusion-controlled.

In Table 2, *[Ru(bpy $\left.)_{3}\right]^{2+}$ emission lifetimes and associated rate constants for oxygen quenching are presented for PSS/Ru $>20$, where single exponential decays are observed. For $\left[\mathrm{Ru}(\mathrm{bpy})_{3}\right]^{2+}$ at $\mathrm{PSS} / \mathrm{Ru}<20$ both lifetimes are quenched by oxygen. In all cases, $k_{q}$ values from intensity and lifetime data are virtually identical $\left(0.9 \pm 0.1 \times 10^{9} \mathrm{M}^{-1} \mathrm{~s}^{-1}\right)$. The apparent rate constant for quenching of $\left[\mathrm{Ru}(\mathrm{bpy})_{3}\right]^{2+}$ by $\mathrm{O}_{2}$ in the presence of PSS is about a quarter of the value in aqueous solution (ESI, Fig. S4), the same ratio as previously report from more limited data. ${ }^{29}$

$k_{q}$ for non-covalently bound $\left[\mathrm{Ru}(\mathrm{bpy})_{3}\right]^{2+}$ is equivalent to that obtained for RuB-PSS, where diffusion of the ruthenium

Table 2 Rate constants for quenching $\left(k_{q}\right)$ of $\left[\mathrm{Ru}(\mathrm{bpy})_{3}\right]^{2+}$ by $\mathrm{O}_{2}$ in the presence of PSS

\begin{tabular}{lcllll}
\hline$[\mathrm{PSS}] / \mathrm{mM}$ & $\mathrm{PSS} / \mathrm{Ru}$ & $\tau_{\text {ox }} / \mathrm{ns}$ & $\tau_{\text {aer }} / \mathrm{ns}$ & $\tau_{\text {deox }} / \mathrm{ns}$ & $k_{q} / 10^{9} \mathrm{M}^{-1} \mathrm{~s}^{-1}$ \\
\hline 0 & 0 & 140 & 360 & 550 & 3.85 \\
0.4 & 20 & 340 & 585 & 725 & 1.11 \\
0.5 & 25 & 355 & 600 & 745 & 1.05 \\
1.0 & 50 & 375 & 630 & 730 & 0.92 \\
1.5 & 75 & 390 & 650 & 750 & 0.87 \\
2.0 & 100 & 380 & 665 & 760 & 0.93 \\
RuB-PSS & 19 & - & 540 & 626 & 0.84
\end{tabular}

Oxygen concentration was varied as described in the experimental section. $\left[\mathrm{O}_{2}\right]=3 \times 10^{-4} \mathrm{M}$ in water at ambient atmosphere (aer), $1.4 \times 10^{-3} \mathrm{M}$ in $\mathrm{O}_{2}$-saturated water (ox), and insignificant in argonsaturated water $($ deox $) .^{45}\left[\left[\mathrm{Ru}(\mathrm{bpy})_{3}\right]^{2+}\right]=2 \times 10^{-5} \mathrm{M}$. complex is essentially eliminated during the emission lifetime. Thus, in respect of neutral small molecule quenching, the two systems behave very similarly.

Theoretical values for the diffusion-controlled rate constant, $k_{d}$, in aqueous solution can be calculated from collision radii of $\left[\mathrm{Ru}(\mathrm{bpy})_{3}\right]^{2+}$ and $\mathrm{O}_{2}$ (see ESI). $k_{d} \sim 10^{10} \mathrm{M}^{-1} \mathrm{~s}^{-1}$ is predicted for freely diffusing species in water. If the diffusion of $\left[\mathrm{Ru}(\mathrm{bpy})_{3}\right]^{2+}$ is completely restricted, $k_{d}$ is reduced by $25 \%$ (see ESI). The observed reduction in the quenching rate constant is much greater than this. This suggests that either the local concentration of $\mathrm{O}_{2}$ in the vicinity of PSS-bound $\left[\mathrm{Ru}(\mathrm{bpy})_{3}\right]^{2+}$ is significantly lower than in aqueous solution, or that diffusion of $\mathrm{O}_{2}$ is retarded in the polyelectrolyte environment. An alternative explanation is that $\left[\mathrm{Ru}(\mathrm{bpy})_{3}\right]^{2+}$ is less accessible to $\mathrm{O}_{2}$ when bound to the polyelectrolyte; however, the open configuration predicted by molecular dynamics simulations (below) suggests that this could be a minor effect. $\mathrm{O}_{2}$ is more soluble in hydrophobic solvents, ${ }^{46}$ but less soluble at increased ionic strengths; ${ }^{47}$ the polyelectrolyte chain is both hydrophobic and a salt, so it is difficult to predict how it will influence local $\mathrm{O}_{2}$ concentration. The local viscosity of the PSS microenvironment $(150 \mathrm{cP}=0.15 \mathrm{~Pa} \mathrm{~s})$ has been reported to be two orders of magnitude higher than that of water $\left(1 \mathrm{cP}=10^{-3} \mathrm{~Pa} \mathrm{~s}\right){ }^{48}$ That would produce a hundred-fold drop in the diffusioncontrolled rate constant, which is much larger than observed. It appears that $\mathrm{O}_{2}$ experiences a PSS viscosity lower than that reported, but higher than water. Therefore, we attribute the reduced quenching by $\mathrm{O}_{2}$ in PSS to a combination of three factors: increased microviscosity near the polyelectrolyte chain, reduced $\mathrm{O}_{2}$ concentration in the polyanion field, and possibly also reduced accessibility of $\mathrm{O}_{2}$ to bound $\left[\mathrm{Ru}(\mathrm{bpy})_{3}\right]^{2+}$.

\section{The effect of salts on the emission of $\left[\operatorname{Ru}(b p y)_{3}\right]^{2+}$ in the presence of PSS}

The effects of sodium chloride $(\mathrm{NaCl})$ on the luminescence lifetimes of the $\left[\mathrm{Ru}(\mathrm{bpy})_{3}\right]^{2+} / \mathrm{PSS}$ system in aerated and deaerated conditions are shown in Fig. 4.

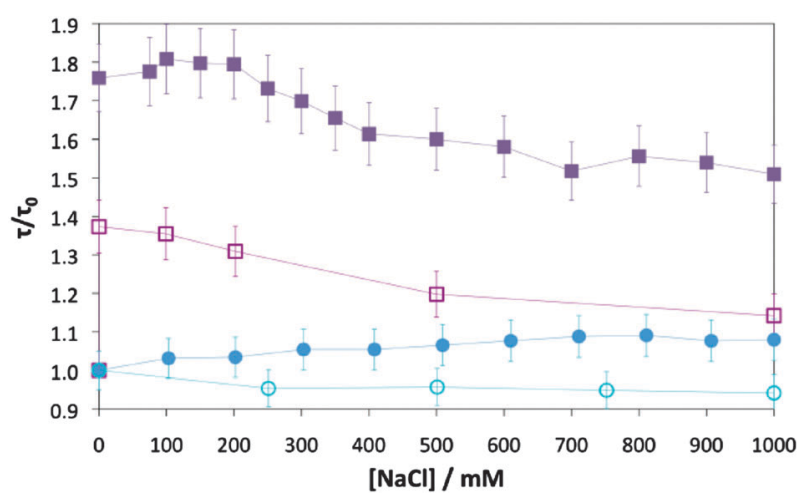

Fig. 4 The effect of sodium chloride on the relative emission lifetime of $\left[\mathrm{Ru}(\mathrm{bpy})_{3}\right]^{2+}$ in aqueous solution. Aqueous solution in air (O); aqueous solution under argon (O); with PSS in air ( $\square$ ); with PSS under argon ( $\square$ ). $\tau_{0}$ is the lifetime in the absence of PSS. $\left[\left[\mathrm{Ru}(\mathrm{bpy})_{3}\right]^{2+}\right]=2 \times 10^{-5} \mathrm{M}$. [PSS $]=1 \times 10^{-3} \mathrm{M}$. PSS $/ \mathrm{Ru}=50$. $\lambda_{\mathrm{ex}}=465 \mathrm{~nm}$ (isosbestic point). 
In air, the lifetime increases slightly on addition of $\mathrm{NaCl}$, before falling to a value at $1 \mathrm{M} \mathrm{NaCl}$ which is substantially lower than that for salt-free $\left[\mathrm{Ru}(\mathrm{bpy})_{3}\right]^{2+} / \mathrm{PSS}$. However, the intensity remains greater than that in the absence of polyelectrolyte, even taking account of the increase in $\left[\mathrm{Ru}(\mathrm{bpy})_{3}\right]^{2+}$ emission lifetime caused by added $\mathrm{NaCl}$ in aqueous solution. The reversal of luminescence enhancement observed upon addition of salt to the $\left[\mathrm{Ru}(\mathrm{bpy})_{3}\right]^{2+} / \mathrm{PSS}$ system is attributed to the metal ions displacing the ruthenium complex from the polymer domain.

In the absence of oxygen, the lifetime falls immediately on addition of $\mathrm{NaCl}$, but at $1 \mathrm{M} \mathrm{NaCl}$ does not drop to the value observed in the absence of PSS. Notably, the emission lifetime of aqueous $\left[\mathrm{Ru}(\mathrm{bpy})_{3}\right]^{2+}$ in air increases in the presence of $\mathrm{NaCl}$, while that in degassed solution decreases. The shorter lifetime in degassed solution reflects increased non-radiative decay with increasing ionic strength, possibly due to formation of ion-pairs. The lifetime increase in air reflects additionally the counteracting effect of reduced oxygen quenching, due to lower oxygen concentrations at higher ionic strengths. ${ }^{47}$

As well as altering the oxygen concentration in aqueous solution, an increase in salt concentration affects the conformation and dynamics of PSS. Water is a good solvent for $\mathrm{PSS},{ }^{49}$ so at low ionic strength the polymer is swollen and expanded. However, at high ionic strength the dimensions of the polyelectrolyte decrease, i.e. the polymer "shrinks" to a more compact configuration due to condensation of the salt cation. The interactions between $\left[\mathrm{Ru}(\mathrm{bpy})_{3}\right]^{2+}$ and PSS may thus be enhanced with increased ionic strength, causing an increase in emission lifetime and intensity as better shielding of the chromophore from water causes an additional decrease in non-radiative decay. Upon shrinking, the polyelectrolyte should also shield the chromophore from oxygen to a greater extent than previously and thus oxygen quenching is further reduced.

The very high salt concentrations $(>1 \mathrm{M})$ required to completely displace $\left[\mathrm{Ru}(\mathrm{bpy})_{3}\right]^{2+}$ into solution demonstrate the great affinity that the complex cation has for the PSS which cannot be purely electrostatic. It has been reported that neutral urea, which interacts through van der Waals and H-bonds, can also displace $\left[\mathrm{Ru}(\mathrm{bpy})_{3}\right]^{2+}$ from PSS, ${ }^{24}$ indicating the importance of non-coulombic interactions in this system.

Similar behaviour was observed on addition of $\mathrm{MgCl}_{2}$ (Fig. 5) to $\left[\mathrm{Ru}(\mathrm{bpy})_{3}\right]^{2+} /$ PSS. In air, a significant emission enhancement is observed (from $I / I_{0} \sim 1.8$ to $\sim 2.0$ ), followed by a gradual decrease to values greater than that in purely aqueous solution. The initial increase can be attributed in part to decreased oxygen solubility as $\mathrm{MgCl}_{2}$ is added. ${ }^{47}$ However, such enhancement should be no greater than that observed in Fig. 4, since $\mathrm{NaCl}$ and $\mathrm{MgCl}_{2}$ have similar effects on oxygen solubility. ${ }^{47}$ In degassed solution, no initial enhancement is observed, so the enhancement does not result from reduced non-radiative decay of $\left[\mathrm{Ru}(\mathrm{bpy})_{3}\right]^{2+}$.

Rather, PSS is more strongly condensed by the small dication $\mathrm{Mg}^{2+}$ than by $\mathrm{Na}^{+}$, since the latter has the potential to coordinate two $\mathrm{SO}_{3}^{-}$groups, as well as having a higher point charge. ${ }^{50}$ The large emission enhancement in the presence of $\mathrm{MgCl}_{2}$ is attributed to such polyelectrolyte condensation, resulting in more limited accessibility of $\mathrm{O}_{2}$ to the Ru binding site. The subsequent emission decrease with increasing salt levels of between 1 and $2 \mathrm{M} \mathrm{MgCl}_{2}$, but the residual emission

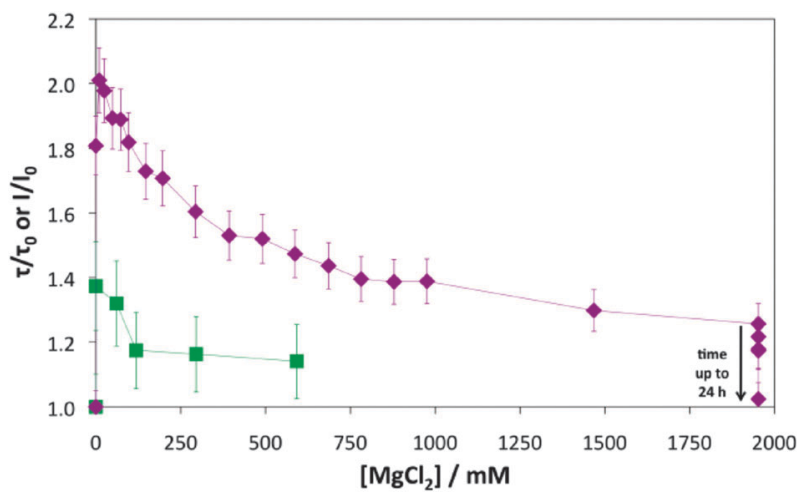

Fig. 5 The effect of magnesium chloride on the relative emission intensity of $\left[\mathrm{Ru}(\mathrm{bpy})_{3}\right]^{2+}$ with PSS in aqueous solution in the presence of air $(\downarrow)$, and on the relative lifetime in $\operatorname{argon}(\square) . \mathrm{I}_{0}$ and $\tau_{0}$ are the intensity and lifetime in the absence of PSS. $\left[\left[\mathrm{Ru}(\mathrm{bpy})_{3}\right]^{2+}\right]=2 \times 10^{-5} \mathrm{M}$. $[\mathrm{PSS}]=1 \times 10^{-3} \mathrm{M} . \mathrm{PSS} / \mathrm{Ru}=50 . \lambda_{\mathrm{ex}}=465 \mathrm{~nm}$ (isosbestic point).

remains $25 \%$ above that of the free complex in solution. The complexity of the interaction with $\mathrm{MgCl}_{2}$ is shown by the fact that the emission at $2 \mathrm{M} \mathrm{MgCl}_{2}$ drops slowly with time, so that after $24 \mathrm{~h}$ with no further addition of salt, the emission has returned to that of free $\left[\mathrm{Ru}(\mathrm{bpy})_{3}\right]^{2+}$. This suggests very slow reorganisation dynamics of $\mathrm{Mg}^{2+}$-condensed PSS, so that kinetically-"trapped" $\left[\mathrm{Ru}(\mathrm{bpy})_{3}\right]^{2+}$ is slowly released into bulk solution. No such time-dependence of emission was observed for $\left[\mathrm{Ru}(\mathrm{bpy})_{3}\right]^{2+}$ bound to PSS in the presence of $1 \mathrm{M} \mathrm{NaCl}$.

\section{PSS conformation and the microenvironment of bound $\left[\mathrm{Ru}(\mathrm{bpy})_{3}\right]^{2+}$}

As discussed above, polyelectrolyte molecules are highly expanded and relatively rigid in salt-free solution and are condensed with increasing ionic strength. Water and dilute salt solutions are good solvents for polyelectrolytes like $\mathrm{PSS}^{49}$ where the chains are open structures, and a volume at the centre of a polyelectrolyte coil typically contains far more solvent than polymer. As ionic strength increases, the percentage volume of solvent decreases. To fully interpret the behaviour of bound $\left[\mathrm{Ru}(\mathrm{bpy})_{3}\right]^{2+}$ and its interaction with bound quenchers, we must consider the environment that they occupy. The local viscosity has been alluded to above, but an awareness of other PSS chain properties allows us to critically interpret the photophysical and binding data shown above, and the quenching data described below.

PSS structure and dynamics has previously been characterised in the dilute/semidilute concentration range using techniques such as SANS, SAXS conductivity, and viscosimetry. Such studies show that PSS is locally rod-like but globally displays coil-like behaviour. ${ }^{7}$ In salt-free solution, PSS can be described by the presence of stable, anisotropic domains of stiff chains. Addition of salt to screen the electrostatic interaction is believed to destroy the structure of these domains. ${ }^{51}$ Qualitatively, the PSS chain is observed to contract with increasing ionic strength. In contrast, the conformation of the more rigid polyanion dsDNA $\left(L_{t} \sim 150 \mathrm{bp} \sim 51 \mathrm{~nm}\right)$ is invariant with increasing ionic strength. ${ }^{52}$

The total persistence length $\left(L_{t}\right)$ of PSS is the sum of contributions from the intrinsic persistence length $\left(L_{p}\right)$ and the electrostatic persistence length $\left(L_{e}\right)$, the latter of which varies with ionic strength of solution as well as polymer concentration. ${ }^{51}$ 
A dilute solution $(<2.5 \mathrm{mM})$ of PSS at high ionic strength $(\mathrm{NaCl}>150 \mathrm{mM})$ behaves like a neutral polymer in a good solvent, with an intrinsic persistence length of $1.2 \mathrm{~nm} .{ }^{53} L_{t}$ varies with $[\mathrm{NaCl}]$ and has been reported from $40 \mathrm{~nm}\left(I_{s}=0\right)$ to $1.4 \mathrm{~nm}\left(I_{s}=500 \mathrm{mM}\right){ }^{7,54,55}$ Concomitant changes are observed for radius of gyration $\left(R_{g}\right)$ from $108 \mathrm{~nm}\left(I_{s}=1 \mathrm{mM}\right)$ to $40 \mathrm{~nm}\left(I_{s}=500 \mathrm{mM}\right)^{6}$ for $M_{w}=10^{6}$, and for the effective diameter. ${ }^{7}$ For a single PSS molecule $\left(M_{w}=2.6 \times 10^{6}\right), R_{g}$ was estimated as $480 \mathrm{~nm}$ in water and $108 \mathrm{~nm}$ after addition of spermine (a polycationic DNA condensing agent); this 5 -fold decrease in radius translates to 100 -fold decrease in chain volume.

\section{Molecular dynamics simulations of PSS conformation in the presence of bound and tethered $\left[R u(b p y)_{3}\right]^{2+}$}

To complement our binding studies, and understand the polymer environment that results in the photophysical changes, we have carried out molecular dynamics simulations of NaPSS chains in water in the absence and presence of added $\left[\mathrm{Ru}(\mathrm{bpy})_{3}\right]^{2+}$, and also for the copolymer (RuB-NaPSS) with tethered $\left[\mathrm{Ru}(\mathrm{bpy})_{3}\right]^{2+}$.

Fig. 6A shows the minimised structure for an isotactic $20 \mathrm{mer}$ of NaPSS in a dielectric continuum representing water $\left(\varepsilon_{r}=77.73\right)$. A comparable result was obtained when simulations were carried out in a box containing explicit water molecules, but the calculation was substantially longer. Therefore, the dielectric continuum was used to compare different systems. An isotactic chain was used for comparison since it represents a single isomer, even though our chains are likely atactic.

Starting from an extended conformation of the chain, the simulations show no tendency for the chain to adopt a coiled or globular conformation. The plane of the benzene ring tends to lie approximately perpendicular to the extended backbone. The aromatic residues arrange around the backbone to minimize steric and electrostatic repulsions, whilst maximising

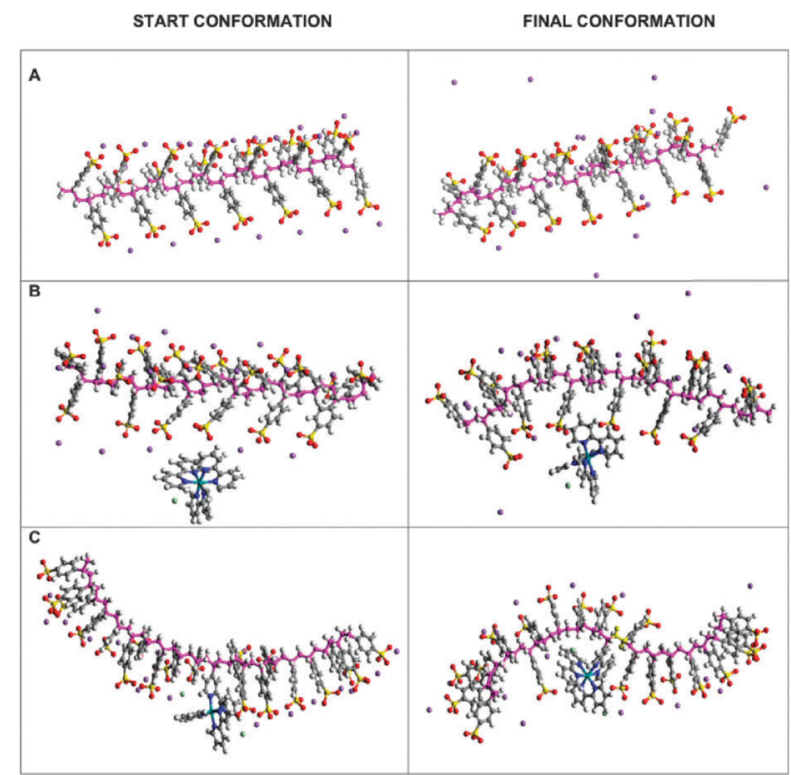

Fig. 6 Calculated MM/MD conformation of (A) 20mer PSS chain; (B) 20 mer PSS chain complexed with $\left[\mathrm{Ru}(\mathrm{bpy})_{3}\right]^{2+}$; (C) 20mer RuB-PSS (19:1) copolymer. attractive non-covalent interactions between the aromatic rings. Hence, the sterically preferred fully trans-conformation is not exclusive, and in this case the styrenesulfonate moieties appear to adopt a pseudo-helical conformation. Stacking interactions between aromatic residues are consistent with the hypochromicity of isotactic PSS compared to syndiotactic PSS. ${ }^{56}$ Molecular dynamics simulations were also carried out with non-covalently bound $\left[\mathrm{Ru}(\mathrm{bpy})_{3}\right]^{2+}$ replacing two sodium ions at PSS $/ \mathrm{Ru}=19$, and for the 19:1 copolymer RuB-PSS. In the starting structures, the ruthenium complexes were placed at the centre of $20 \mathrm{mer}$ segments. Non-covalently-bound $\left[\mathrm{Ru}(\mathrm{bpy})_{3}\right]^{2+}$ molecules were placed close to the PSS chain, but with no van der Waals interactions. For the covalentlybound complex, the ruthenium centre lies close to the sulfonate groups, so that the tethered bipyridine ligand is adjacent to the phenyl groups. Results from the simulations were similar for 20mer, 60mer and 100mer chains (ESI, Fig. S9-S11). These low concentrations of ruthenium complexes gave rise to local curvature of the polyelectrolyte, but did not cause major conformation changes such as those associated with formation of globules or blobs. The polymer chains remain in open conformations and the ruthenium complexes are still highly exposed to solvent in all structures.

In the final structures, the PSS chains tended to curve around the ruthenium complexes, with more marked curvature for the covalently-bound complex. Free $\left[\mathrm{Ru}(\mathrm{bpy})_{3}\right]^{2+}$ complexes were observed to locate close to the polymer as the simulation progressed, but the bipyridine ligands only occasionally adopted positions indicative of $\pi$-stacking with PSS phenyl groups. For the copolymer, the complex was more deeply embedded in the polymer chain; the phenyl sulfonate groups adjacent to the ruthenium complex took trans positions which facilitated local curvature, and the bipyridine ligands approached the polyethene backbone. Thus, the attractive hydrophobic environment afforded by the polyelectrolyte results primarily from the non-polar nature of the polystyrene segments, and exclusion of aqueous solvent, rather than from aromatic $\pi-\pi$ stacking interactions.

Our findings for PSS chains in the absence of ruthenium complex are consistent with a previous molecular dynamics study of NaPSS-PS copolymers in water. ${ }^{57}$ Stretched chain conformations were observed for fully sulfonated PSS, though collapse into globules was observed as the linear charge density decreased when the percentage of PS in the copolymer increased; for PSS, $R_{g}$ scaled with $N$, the number of repeat units. In the copolymer globules, the ionized groups were located on the surface, minimizing electrostatic repulsion and maximizing attractive interactions with solvent. With increasing salt concentrations, as PSS starts to behave like a neutral polymer, similar globular chain conformations will be formed.

The MD images substantiate our interpretations of the photophysics data. The images demonstrate the importance of electrostatic and hydrophobic interactions with the polyelectrolyte, and show how the chains tend to curve at the complex binding positions. Restricted diffusion within this environment is obvious. The graphics indicate that the complexes experience an environment that has lower water activity than bulk solution, but is still substantially aqueous. 


\section{Quenching of $\left[\operatorname{Ru}(\mathrm{bpy})_{3}\right]^{2+}$ and RuB-PSS emission by $\mathrm{MV}^{2+}$}

$\left[\mathrm{Ru}(\mathrm{bpy})_{3}\right]^{2+}$ undergoes photosensitized electron transfer with methyl viologen $\left(\mathrm{MV}^{2+}\right)$, producing a reduced viologen radical cation (eqn (3)). All reactants and products are cationic and can bind electrostatically as well as hydrophobically to PSS.

$$
*\left[\mathrm{Ru}(\mathrm{bpy})_{3}\right]^{2+}+\mathrm{MV}^{2+} \rightarrow\left[\mathrm{Ru}(\mathrm{bpy})_{3}\right]^{3+}+\mathrm{MV}^{\bullet+}
$$

Understanding the effect of PSS on the $*\left[\mathrm{Ru}(\mathrm{bpy})_{3}\right]^{2+} / \mathrm{MV}^{2+}$ system facilitates interpretation of quenching data for the covalently-tethered ruthenium complex and quenching by a zwitterionic viologen. Adding to previous studies, we have studied the quenching of both the luminescence and lifetime of $*\left[\mathrm{Ru}(\mathrm{bpy})_{3}\right]^{2+}$, and our results are comparable. ${ }^{28,29}$

The apparent rate constant for quenching determined from luminescence quenching at low $\left[\mathrm{MV}^{2+}\right]$ is increased substantially when both reactants are bound non-covalently to the anionic polymer (i.e., when [PSS] $>$ [Q]), consistent with increased local concentrations of cations in the polyanion field (Table 3). The 22-fold increase in $k_{q}$ is in line with the 17-fold increase observed by Park et al. ${ }^{29}$ However, when the quencher concentration rises above that of the PSS, the quenching becomes less efficient, and the luminescence rate constant is diffusion-controlled.

The rate constants obtained from lifetime Stern-Volmer plots are lower than those observed from intensity plots (Table 3) and the plots do not show significant curvature (ESI, Fig. S5); indeed the $k_{q}$ values are even lower than those observed in solution, despite the binding of both reactants to PSS. This is an indication that static quenching occurs for closely bound $\mathrm{MV}^{2+}$ and $\left[\mathrm{Ru}(\mathrm{bpy})_{3}\right]^{2+}$ molecules, with a lifetime below the detection limit of our SPC apparatus ( $<1 \mathrm{~ns})$. The residual slow lifetime quenching likely arises from diffusional quenching within the somewhat higher viscosity environment $\left(c f . \mathrm{O}_{2}\right.$ quenching) of the polyelectrolyte. Our time-resolved data substantiates a previous suggestion that static quenching plays a role in this system. ${ }^{29}$

For the copolymer RuB-PSS, quenching by $\mathrm{MV}^{2+}$ is markedly different. The Stern-Volmer intensity plot slopes strongly upwards (Fig. 7), so that at high $\mathrm{MV}^{2+}$ concentrations the quenching is greater than for the non-covalently bound compound. The quenching rate constant calculated from the initial slope is smaller than that for non-covalently bound $\left[\mathrm{Ru}(\mathrm{bpy})_{3}\right]^{2+}$, but still higher than that observed in solution. A quenching sphere-of-action plot - $\ln \left(I_{0} / I\right) v s$. $\left[\mathrm{MV}^{2+}\right]$ - yields a straight line with slope $18300 \mathrm{M}^{-1}$, which gives a radius of $19.2 \mathrm{~nm}$. This is unrealistically large, since for the $\left[\mathrm{Ru}(\mathrm{bpy})_{3}\right]^{2+} / \mathrm{MV}^{2+}$ system in glycerol the quenching radius is $1.3 \mathrm{~nm} .{ }^{58}$

Table 3 Influence of PSS on the initial rate constants for intensity and lifetime quenching of $*\left[\mathrm{Ru}(\mathrm{bpy})_{3}\right]^{2+}$ by $\mathrm{MV}^{2+}$ in aqueous solution in air, calculated from initial slopes of Stern-Volmer Plots

\begin{tabular}{lclll}
\hline & & \multicolumn{2}{l}{$k_{q} / \mathrm{dm}^{3} \mathrm{~mol}^{-1} \mathrm{~s}^{-1}$} & $\begin{array}{l}k_{q} / \mathrm{dm}^{3} \mathrm{~mol}^{-1} \mathrm{~s}^{-1} \\
\tau_{0} / \tau\end{array}$ \\
\hline PSS $] / \mathrm{mM}$ & PSS $/ \mathrm{Ru}$ & $\tau_{0} / \mathrm{ns}$ & $I_{0} / I$ & $9.3 \times 10^{8}$ \\
1 & 0 & 360 & $4.5 \times 10^{-8}$ & $6.1 \times 10^{8}$ \\
RuB-PSS & 40 & 560 & $2.5 \times 10^{11}$ & - \\
{$\left[\left[\mathrm{Ru}(\text { bpy })_{3}\right]^{2+}\right]=2.5 \times 10^{-5} \mathrm{M}$.} &
\end{tabular}

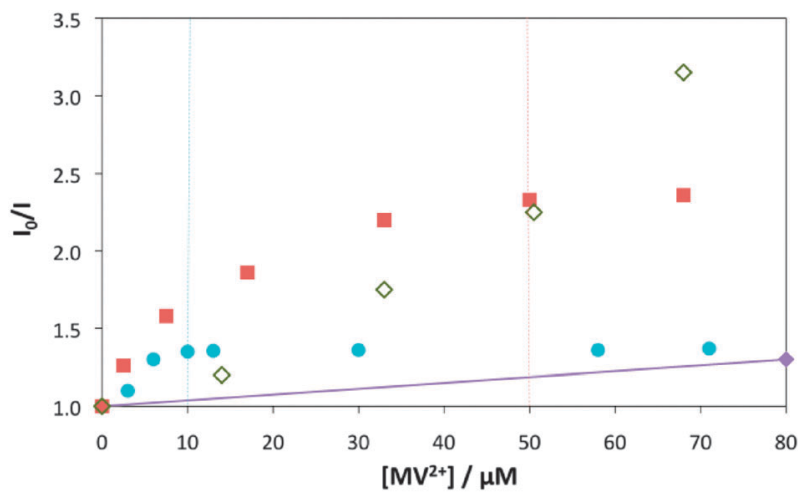

Fig. 7 Effect of PSS on the intensity quenching of $*\left[\mathrm{Ru}(\mathrm{bpy})_{3}\right]^{2+}$ by $\mathrm{MV}^{2+}$ in air. $\left.[\mathrm{PSS}]=0(\diamond) ; \mathrm{PSS}\right]=1 \times 10^{-5} \mathrm{M}, \mathrm{PSS} / \mathrm{Ru}=0.5(\bigcirc)$; $[\mathrm{PSS}]=5 \times 10^{-5} \mathrm{M}, \mathrm{PSS} / \mathrm{Ru}=2.5(\square) ; \mathrm{RuB}-\mathrm{PSS}, \mathrm{PSS} / \mathrm{Ru}=19(\diamond)$. $\left[\mathrm{Ru}^{\mathrm{II}}\right]=2 \times 10^{-5} \mathrm{M}$.

Instead, the non-linearity of the Stern-Volmer plot may arise from the approximation of using the bulk quencher concentration as an estimate of the effective quencher concentration. The increased rate constant for quenching of RuB-PSS by $\mathrm{MV}^{2+}$ in PSS compared to water is interpreted in terms of an increased quencher concentration in the vicinity of * RuB-PSS. However, the quenching rate constant for $\left[\mathrm{Ru}(\mathrm{bpy})_{3}\right]^{2+}$ noncovalently bound to PSS is higher than that for the copolymer, indicating that the complex is more accessible to quencher when not closely attached to the polyanion backbone. This contrasts with the virtually identical rate constants obtained for both systems with oxygen as quencher.

Since $\mathrm{MV}^{2+}$ is aromatic, we compared its quenching ability with that of a simple non-hydrophobic cation. Upward curvature in the Stern-Volmer Plot was not observed when *RuB-PSS was quenched by $\mathrm{Fe}^{3+}$ ions (ESI, Fig. S6), and the rate constant $\left(1.5 \times 10^{11} \mathrm{dm}^{3} \mathrm{~mol}^{-1} \mathrm{~s}^{-1}\right)$ was higher than that obtained from the initial slope of the $\mathrm{MV}^{2+}$ Stern-Volmer Plot $\left(2.5 \times 10^{11} \mathrm{dm}^{3} \mathrm{~mol}^{-1} \mathrm{~s}^{-1}\right)$. At higher $\mathrm{MV}^{2+}$ concentrations, the rate constant rises to a higher value $\left(5 \times 10^{11} \mathrm{dm}^{3} \mathrm{~mol}^{-1} \mathrm{~s}^{-1}\right)$ than that for $\mathrm{Fe}^{3+}$. Therefore, although the quenching of the covalently-bound $\mathrm{Ru}$ complex by $\mathrm{MV}^{2+}$ is faster than that of the free complex in solution, at low concentrations of added $\mathrm{MV}^{2+}$ it is retarded compared to quenching by a $\mathrm{Fe}^{3+}$ in PSS. Hence, $\mathrm{MV}^{2+}$ interacts with PSS in a manner which prevents it from reacting readily with the tethered ruthenium centre, but allows it to react efficiently with non-covalently bound $\left[\mathrm{Ru}(\mathrm{bpy})_{3}\right]^{2+}$. The comparison with $\mathrm{Fe}^{3+}$ suggests that the aromatic nature of $\mathrm{MV}^{2+}$ results in hydrophobic interactions with PSS which cause this retardation.

We envisage that at low concentrations, $\mathrm{MV}^{2+}$ is bound to RuB-PSS in positions removed from covalently bound complex and that there is slow diffusion of reactants within the lifetime of the ruthenium chromophore. When $\left[\mathrm{MV}^{2+}\right]$ is raised, the additional quenchers molecules bind in locations which are either closer to the ruthenium complex and/or where they have greater freedom to diffuse, producing more efficient quenching and a non-linear Stern-Volmer Plot. With noncovalently bound $\left[\mathrm{Ru}(\mathrm{bpy})_{3}\right]^{2+}$, there is competition for all sites between lumiphore and quencher and both species can diffuse, albeit more slowly than in solution; the quenching rate constant is thus higher than for RuB-PSS. 


\section{Quenching of $\left[\left.\mathrm{Ru}(\mathrm{bpy})_{3}\right|^{2+}\right.$ and RuB-PSS emission by $\mathrm{PVS}^{\mathbf{0}}$}

Propyl viologen sulfonate $\left(\mathrm{PVS}^{0}\right)$ is formally neutral but has a redox properties similar to $\mathrm{MV}^{2+}\left(\mathrm{E}^{0}\left[\mathrm{PVS}^{0} / \mathrm{PVS}^{\bullet}{ }^{-}\right]=-0.41 \mathrm{~V}\right.$ vs. NHE; cf. $\mathrm{E}^{0}\left(\mathrm{MV}^{2+} / \mathrm{MV}^{\bullet+}\right)=-0.45 \mathrm{~V}$ vs. NHE) ${ }^{60}$ Photosensitized electron transfer from *[Ru(bpy $\left.)_{3}\right]^{2+}$ to $\mathrm{PVS}^{0}$ gives an viologen anion radical product.

$$
{ }^{*}\left[\mathrm{Ru}(\mathrm{bpy})_{3}\right]^{2+}+\mathrm{PVS}^{0} \rightarrow\left[\mathrm{Ru}(\mathrm{bpy})_{3}\right]^{3+}+\mathrm{PVS}^{\bullet-}
$$

The rate constant for quenching of $*\left[\mathrm{Ru}(\mathrm{bpy})_{3}\right]^{2+}$ by $\mathrm{PVS}^{0}$ in aerated aqueous solution is measured to be $k_{q}=1.5 \times 10^{9} \mathrm{M}^{-1} \mathrm{~s}^{-1}$ (for $\tau_{0}=360 \mathrm{~ns}$ ). This agrees with previously reported values in solution. ${ }^{59-62}$ No other study has reported the quenching in the presence of PSS. We observe that lifetime and intensity data give identical plots in water, but diverge in the presence of PSS.

Stern-Volmer intensity plots for quenching in the presence of PSS are linear, except at PSS/Ru ratios close to 20 where they curve upwards at high quencher concentrations. Quenching in the presence of PSS is more efficient than in aqueous solution. The extent of quenching (the Stern-Volmer slope) at a given quencher concentration increases up to PSS $/ \mathrm{Ru} \sim 20$. As $\mathrm{PSS} / \mathrm{Ru}$ increases beyond 20, the rate of quenching decreases again, so that at PSS/Ru>1000 the extent of quenching approaches that in the absence of PSS (ESI, Fig. S7).

Intensity quenching data at low $\left[\mathrm{PVS}^{0}\right]$ were fitted with the linear Stern-Volmer equation to give quenching rate constants, $k_{q}$, using the emission lifetimes in the absence of quencher at the respective PSS concentration. In Fig. 8, $k_{q}$ is plotted against $\mathrm{PSS} / \mathrm{Ru}$ for different data sets, and is seen to be maximal at $\mathrm{PSS} / \mathrm{Ru} \sim 20$, with a 3-4-fold increase over that in water.

Stern-Volmer plots for lifetime data do not show marked upward curvature at any PSS/Ru. Although the extent of lifetime quenching increases with added PSS, this is accounted for entirely by the increased lifetime of $*\left[\operatorname{Ru}(b p y)_{3}\right]^{2+}$ bound to PSS. It transpires that $k_{q}$ values derived from lifetime data do not vary significantly as PSS is added. The emission decay is always bi-exponential for PSS $/ \mathrm{Ru}<20$, and both lifetime components are quenched with the same rate constant.

The difference between the lifetime and intensity data (Table 4) indicates that, as with $\mathrm{MV}^{2+}$, static quenching occurs in the $\left[\mathrm{Ru}(\mathrm{bpy})_{3}\right]^{2+} / \mathrm{PVS}^{0}$ redox system in the presence of PSS,

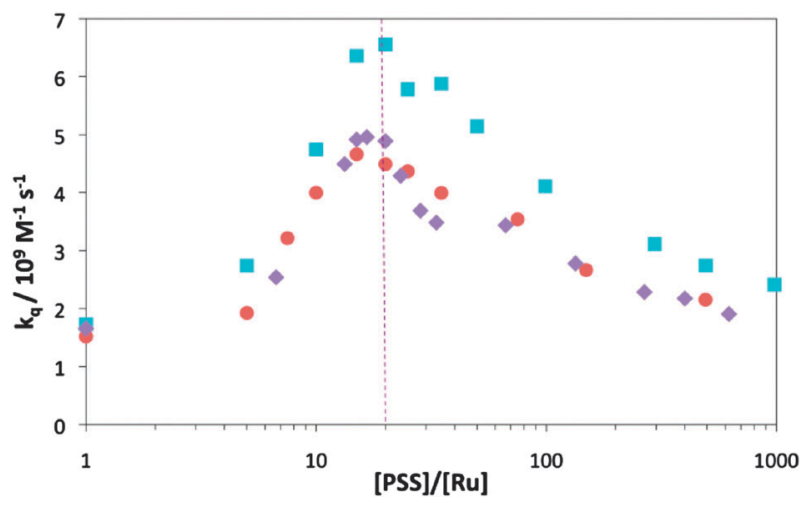

Fig. 8 The rate constant for intensity quenching $\left(k_{q}\right)$ of $*\left[\mathrm{Ru}(\mathrm{bpy})_{3}\right]^{2+}$ by $\mathrm{PVS}^{0}$ in the presence of PSS in air, as a function of PSS/Ru ratio. $\left[\left[\operatorname{Ru}(\mathrm{bpy})_{3}\right]^{2+}\right]=10 \mu \mathrm{M}(\square), 20 \mu \mathrm{M}(\odot)$, and $30 \mu \mathrm{M}(\bullet)$.
Table 4 Influence of PSS on the rate constants for intensity and lifetime quenching of $*\left[\mathrm{Ru}(\mathrm{bpy})_{3}\right]^{2+}$ by $\mathrm{PVS}^{0}$ in aqueous solution in air, calculated from slopes of Stern-Volmer Plots

\begin{tabular}{lclll}
\hline & & $\begin{array}{l}k_{q} / \mathrm{dm}^{3} \mathrm{~mol}^{-1} \mathrm{~s}^{-1} \\
{[\mathrm{PSS}] / \mathrm{mM}}\end{array}$ & $\mathrm{PSS} / \mathrm{Ru}$ & $k_{0} / \mathrm{dm}^{3} \mathrm{~mol}^{-1} \mathrm{~s}^{-1}$ \\
$I_{0} / I$ & $1.3 \times 10^{9}$ \\
\hline 0 & 0 & 360 & $1.5 \times 10^{9}$ & $1.6 \times 10^{9}$ \\
1 & 20 & 585 & $5.0 \times 10^{9}$ & 1.6 \\
RuB-PSS & 19 & 540 & $0.1 \times 10^{9}$ & - \\
{$\left[\left[\mathrm{Ru}(\mathrm{bpy})_{3}\right]^{2+}\right]=2 \times 10^{-5} \mathrm{M}$.} & \\
\hline
\end{tabular}

resulting in a fraction of the ruthenium chromophores having a lifetime below our SPC detection limit $(<1 \mathrm{~ns})$. This effect is most marked at the PSS $/ \mathrm{Ru}=20$, when $\left[\mathrm{Ru}(\mathrm{bpy})_{3}\right]^{2+}$ and $\mathrm{PVS}^{0}$ are likely to be bound in close proximity in the PSS matrix (Fig. 9).

Comparison of intensity quenching for RuB-PSS and $\left[\mathrm{Ru}(\mathrm{bpy})_{3}\right]^{2+}$ in water shows that covalently tethering the ruthenium chromophore to the polymer backbone strongly retards quenching (ESI, Fig. S8). This is reminiscent of our observations with $\mathrm{MV}^{2+}$, where the quenching rate constant is smaller for RuB-PSS compared to non-covalently bound $\left[\mathrm{Ru}(\mathrm{bpy})_{3}\right]^{2+}$, but the effect is much more marked with $\mathrm{PVS}^{0}$ as quencher so that the quenching is even slower than that observed in solution. Of course, $\mathrm{MV}^{2+}$ quenching is enhanced by the shielding of repulsive coulombic forces when the reactants are bound to PSS, which does not occur for $\mathrm{PVS}^{0}$. Apart from that effect, we surmise that the reasons for reduced quenching of RuB-PSS are similar in physical basis to those proposed for $\mathrm{MV}^{2+}$; viz. separate binding regimes for lumiphore and hydrophobic quencher, and reduced diffusion in the polymer environment.

In equilibrium dialysis experiments in $50 \mathrm{mM} \mathrm{NaCl}$ (to eliminate Donnan effects), we found no evidence that PVS $^{0}$ partitioned in favour of PSS; hence, binding must be weak under such conditions. All electron transfer experiments were carried out without added salt, where $\mathrm{PVS}^{0}$ appears to interact more strongly with PSS. On the basis that quenching occurs more efficiently with PSS than in bulk solution and that there is an indication of static quenching, $\mathrm{PVS}^{0}$ must bind in a similar PSS environment to $\left[\mathrm{Ru}(\mathrm{bpy})_{3}\right]^{2+}$. Moreover, addition of excess PSS to the RuB-PSS $/ \mathrm{PVS}^{0}$ redox pair results in reduced quenching, which suggests that $\mathrm{PVS}^{0}$ has a significant
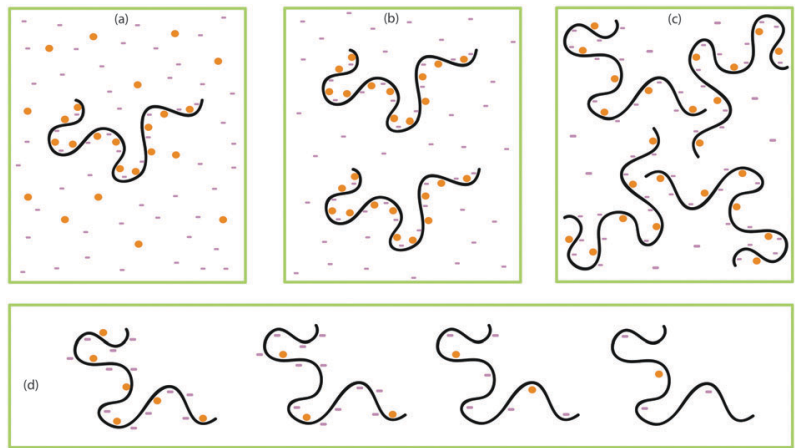

Fig. 9 Schematic model for binding of $\left[\mathrm{Ru}(\mathrm{bpy})_{3}\right]^{2+}$ and quencher to $\mathrm{PSS}$ at different $\mathrm{R} / \mathrm{Ru}$ values, where $[\mathrm{Q}] \gg[\mathrm{Ru}]$. Distribution of $\mathrm{Ru}$ $(\odot)$ and $\mathrm{Q}(\bullet)$ on PSS chains where $[\mathrm{Ru}]$ and $[\mathrm{Q}]$ are fixed and $[\mathrm{P}]$ increases so that (a) PSS $/ \mathrm{Ru}=10$; (b) PSS $/ \mathrm{Ru}=20$; (c) $\mathrm{PSS} / \mathrm{Ru}=40$. (d) Distribution of molecules on a single polyelectrolyte chain as PSS/Ru increases above 40, and [PSS] becomes larger than [Q]. 
interaction with PSS. The lack of observable interaction at higher salt concentration suggests that the binding is partially electrostatic as well as hydrophobic, suggesting that the PSS sulfonate groups compete with the viologen sulfonates to interact with the pyridinium sites of $\mathrm{PVS}^{0}$.

\section{PSS effect on electron transfer cage escape yields}

Nanosecond transient absorption spectra for aqueous $\left[\mathrm{Ru}(\mathrm{bpy})_{3}\right]^{2+},\left[\mathrm{Ru}(\mathrm{bpy})_{3}\right]^{2+} / \mathrm{PSS}$, and the RuB-PSS copolymer were similar within a few nanometres (Table S1). For any system, ground-state recovery $(\sim 455 \mathrm{~nm})$, transient absorption decay $(\sim 366 \mathrm{~nm})$ and luminescence decay $(\sim 617 \mathrm{~nm})$ showed the same mono-exponential kinetics at high PSS concentrations, and these corresponded to the emission decays. No extra short-lived species are observed for the RuB-PSS copolymer, indicating no excited state interaction between the fixed chromophores.

For $\mathrm{MV}^{2+}$ quenching of $*\left[\mathrm{Ru}(\mathrm{bpy})_{3}\right]^{2+} / \mathrm{PSS}$ and *RuB-PSS (in air), the back electron transfer reactions (eqn (5)) were rapid ( $<5 \mathrm{~ns}$ ), and no long-lived products were observed. In aqueous solution (in the absence of PSSS), long-lived cage escape products were observed, since the products repel each other, with a yield of $0.22\left(c f . \phi=0.25^{63}\right)$. Therefore, the anionic environment of PSS promotes both the forward and back electron transfer reactions for this system.

$$
\left[\mathrm{Ru}(\mathrm{bpy})_{3}\right]^{3+}+\mathrm{MV}^{\bullet+} \rightarrow\left[\mathrm{Ru}(\mathrm{bpy})_{3}\right]^{2+}+\mathrm{MV}^{2+}
$$

A lower cage escape yield of 0.12 was observed for $\left[\mathrm{Ru}(\mathrm{bpy})_{3}\right]^{2+} / \mathrm{PVS}^{0}$ in water $\left(c f . \phi=0.14^{63}\right)$ because the products are oppositely charged. It was anticipated that since the product of the $\left[\mathrm{Ru}(\mathrm{bpy})_{3}\right]^{2+} / \mathrm{PVS}^{0}$ electron transfer reaction is formally negatively charged $\left(\mathrm{PVS}^{\bullet-}\right.$ ), it would be repelled by the polyanion into solution, thus retarding the back reaction and enhancing the cage escape yield of redox products. This is observed for $\left[\mathrm{Ru}(\text { bpy })_{3}\right]^{3+} / \mathrm{PVS}^{\bullet-}$ with $\mathrm{SiO}_{2}$ colloid due to repulsion of $\mathrm{PVS}^{\bullet-}$ from negatively charged $\mathrm{SiO}_{2}$ particle surfaces. $^{60}$

However, the cage escape yield was slightly reduced $(\sim 0.10)$ upon addition of PSS. The drop in cage escape yield for noncovalently bound $\left[\mathrm{Ru}(\mathrm{bpy})_{3}\right]^{2+}$ may be connected with the static quenching observed for this system, since reverse electron transfer could be efficient if the reactants are held fixed in close proximity and attract each other. In contrast, the yield was slightly enhanced for the copolymer RuB-PSS (0.18), as initially anticipated. This correlates with the absence of static quenching in the $*\left[\mathrm{Ru}(\mathrm{bpy})_{3}\right]^{2+} / \mathrm{PVS}^{0}$ reaction, so that $\mathrm{PVS}^{\bullet-}$ is more readily repelled, probably due to the more buried location of the covalently bound ruthenium complex. However, the binding of the molecules by PSS, where hydrophobic and microviscosity as well as electrostatic considerations are important, means that only low yields of long-lived reaction products from the neutral quencher are observed, in contrast to observations with $\mathrm{SiO}_{2}{ }^{60}$

\section{PSS as a model for DNA}

One objective of this study was to examine whether PSS can be used to provide a simple model for DNA, to allow the effects of electrostatic and hydrophobic interactions to be discriminated without the complications of binding in specific modes such as intercalation. Although PSS resembles single-stranded (ss) DNA in terms of persistence length, diameter and charge density, ${ }^{6,7}$ the hydrophobic bases and the charged backbone are well separated from each other in the ssDNA strand whilst they are proximal in PSS. The predicted conformation of PSS chains (Fig. 6) places the charges in a pseudo-helical arrangement around a core of the hydrophobic moieties attached to the central polythene backbone $(0.17 \mathrm{~nm}$ rise for monoanionic repeat); in this global view, the PSS strand bears a striking resemblance to the double-stranded DNA structure $(3.4 \mathrm{~nm}$ rise for dianionic repeat) and has a similar linear charge density. The counterion distribution about both PSS and dsDNA can be described by classical Poisson-Boltzmann theory. ${ }^{7}$

The small spectral perturbations for $\left[\mathrm{Ru}(\mathrm{bpy})_{3}\right]^{2+}$ and $\left[\mathrm{Ru}(\text { phen })_{3}\right]^{2+}$ with PSSS are similar to those observed in the presence of ds-DNA. ${ }^{64,65}$ Also, the luminescence enhancements with PSS are virtual identical to those reported with dsDNA for both $\left[\mathrm{Ru}(\mathrm{bpy})_{3}\right]^{2+}$ and $\left[\mathrm{Ru}(\mathrm{phen})_{3}\right]^{2+}$, in deoxygenated, aerated and oxygenated conditions; ${ }^{66,67}$ the $k_{q}$ values for $\mathrm{O}_{2}$ quenching are thus also the same. Moreover, the single exponential decay of PSS-bound $\left[\mathrm{Ru}(\mathrm{bpy})_{3}\right]^{2+}$ and the bi-exponential decay of PSS-bound $\left[\mathrm{Ru}(\mathrm{phen})_{3}\right]^{2+}$ also mirrors the behaviour of these complexes when they are bound to dsDNA. ${ }^{64,66,67}$

These very similar behaviours occur despite the different structures and conformations of the two polyelectrolytes, and the different types of binding interactions that can occur. The binding mode of $\left[\mathrm{Ru}(\mathrm{bpy})_{3}\right]^{2+}$ to dsDNA is weak and probably mainly electrostatic, whilst that of $\left[\mathrm{Ru}(\text { phen })_{3}\right]^{2+}$ is stronger and semi-intercalative. We note, however, that there are limitations to the extent to which PSS acts as a good model for dsDNA, and this happens when a molecule binds specifically via a binding mode that is unique for DNA, e.g. intercalation. We detect only low emission from the DNA intercalator $\left[\mathrm{Ru}(\mathrm{phen})_{2}(\mathrm{dppz})\right]^{2+}$ when it interacts with PSS, similar to the emission with $[$ poly $(\mathrm{dA})]$. $\left[\mathrm{Ru}(\mathrm{phen})_{2}(\mathrm{dppz})\right]^{2+}$ is non-emissive in water, but emits when intercalated between the DNA basepairs which protects the ring nitrogens from excited state H-bonding to water. ${ }^{68,69}$ Likewise, the emission is strongly enhanced in organic solvents and when bound to SDS, ${ }^{70}$ where water is excluded. Therefore, the binding site in PSS does not exclude water in the way that an intercalation site does, but it mimics the environment of a single-stranded polynucleotide. Nevertheless, we conclude that the PSS environment can model certain aspects of the non-intercalative binding of $\left[\mathrm{Ru}(\mathrm{bpy})_{3}\right]^{2+}$ and semi-intercalation of $\left[\mathrm{Ru}(\mathrm{phen})_{3}\right]^{2+}$ with dsDNA, and behaves as a simple dsDNA model for non-intercalative binders and as a good model for ssDNA.

\section{Summary}

We conclude that $\left[\mathrm{Ru}(\mathrm{bpy})_{3}\right]^{2+}$ binds strongly to the polyelectrolyte PSS by the combined effects of hydrophobic and electrostatic interactions. The binding of the complex to the polymer shields the complex from the aqueous phase which causes a decrease in non-radiative decay and an accompanying increase in luminescence intensity and lifetime, which is similar to the effect observed when $\left[\mathrm{Ru}(\mathrm{bpy})_{3}\right]^{2+}$ binds to DNA. $\left[\mathrm{Ru}(\mathrm{bpy})_{3}\right]^{2+}$ can be removed from the polyelectrolyte domain by addition of large excess of simple electrolytes. 
Molecular dynamics studies show that $\left[\mathrm{Ru}(\mathrm{bpy})_{3}\right]^{2+}$ is bound close to the hydrophobic polystyrene segments of PSS, where it can also interact electrostatically with the anionic sulfonate groups. Neither covalent or non-covalent binding results in major conformational change in the polyelectrolyte, but causes local curvature of the chain around the ruthenium complex. In the absence of added salt, at low concentrations of ruthenium complex, the PSS chains remain in an open extended structure which is accessible to water, consistent with the observation that binding to PSS does not turn on the luminescence of bound $\left[\mathrm{Ru}(\mathrm{phen})_{2} \mathrm{dppz}\right]^{2+}$.

Quenching by the cationic species $\mathrm{MV}^{2+}$ is enhanced, as expected, in the presence of PSS. Quenching by a neutral, nonhydrophobic species $\left(\mathrm{O}_{2}\right)$ is hindered when the complex interacts with the polymer. This occurs because the complex is concentrated close to the polymer but the random distribution of oxygen in solution is not significantly affected. On the other hand, quenching by a hydrophobic, formally neutral quencher $\left(\mathrm{PVS}^{0}\right)$ is enhanced in the presence of PSS. In this case, the quencher as well as the complex is attracted to the vicinity of the polymer by hydrophobic and weak electrostatic interactions, and the reacting species are thus located close to each other.

Tethering the ruthenium complex to the polymer backbone directly via one of its bipyridine ligands inhibits both cationic and zwitterionic viologen electron transfer reactions compared to those of $\left[\mathrm{Ru}(\mathrm{bpy})_{3}\right]^{2+}$ in solution or non-covalently bound to PSS. Quenching by $\mathrm{O}_{2}$, by contrast, has the same rate constant as non-covalently bound $\left[\mathrm{Ru}(\mathrm{bpy})_{3}\right]^{2+}$, and at high concentrations of $\mathrm{MV}^{2+}$ faster quenching is observed. We surmise that at low concentrations, $\mathrm{MV}^{2+}$ and $\mathrm{PVS}^{0}$ are bound to RuB-PSS in positions removed from covalently bound complex and that there is slow diffusion of reactants within the lifetime of $*\left[R u(b p y)_{3}\right]^{2+}$.

Cage escape is eliminated for cationic quenchers in the presence of PSS. There is also no enhancement of cage escape with $\mathrm{PVS}^{0}$, contrary to expectation. Possibly, a hydrophobic interaction exists between PVS ${ }^{\bullet-}$ and PSS which counterbalances the electrostatic repulsion between them, or efficient recombination between locally bound and mutually attractive PVS ${ }^{-}$ and $\left[\mathrm{Ru}(\mathrm{bpy})_{3}\right]^{3+}$ prevents the viologen product from escaping the repulsive polyelectrolyte field. However, for RuB-PSS a small increase in cage escape occurs. This could arise from the more buried location of the ruthenium complex reducing electrostatic attraction and hindering efficient recombination.

Finally, by comparing the photophysical behaviour of ruthenium complexes bound to PSS and DNA, we conclude that PSS provides a tenable simplified model for some aspects of the binding and assembly of reactants on dsDNA. The binding to PSS of tris-bidentate ruthenium complexes that are not classical intercalators, mirrors very closely their behaviour with dsDNA, in terms of hydrophobic as well as electrostatic attraction and also associated spectroscopic changes. Only for binding of a strong intercalator, e.g. $\left[\mathrm{Ru}(\mathrm{phen})_{2}(\mathrm{dppz})\right]^{2+}$, does the model fail, because PSS cannot reproduce the water-excluding environment of the DNA intercalation pocket although it does reproduce the binding to ssDNA. The influence of PSS on electron transfer reactions can thus inform studies of electron transfer in between non-intercalating reactants assembled on DNA. ${ }^{8,9}$

\section{Abbreviations}

\begin{tabular}{|c|c|}
\hline PAA & polyacrylic acid \\
\hline PES & polyvinylsulfate \\
\hline PSS & polystyrenesulfonate \\
\hline PS & polystyrene \\
\hline SDS & sodium dodecylsulfate \\
\hline RuB-PSS & $\begin{array}{l}19: 1 \quad[\text { sodium polystyrenesulfonate]- } \\
{\left[\mathrm{Ru}(\mathrm{bpy})_{2}\left(\mathrm{bpy}^{\prime}\right)\right]^{2+} \text { copolymer, where bpy }=} \\
\text { 4-vinyl-2,2'-bipyridine }\end{array}$ \\
\hline$[\operatorname{poly}(\mathrm{dT})]$ & polydeoxythymidylic acid \\
\hline$*\left[\mathrm{Ru}(\mathrm{bpy})_{3}\right]^{2+}$ & excited state ruthenium tris $\left(2,2^{\prime}\right.$-bipyridine $)$ \\
\hline bpy & $2,2^{\prime}$-bipyridine \\
\hline phen & 1,10-phenanthroline \\
\hline $\mathrm{dmb}$ & $4,4^{\prime}$-dimethyl-2,2'-bipyridine \\
\hline dip & diphenylphenanthroline \\
\hline $\mathrm{MV}^{2+}$ & methyl viologen (1,1'-dimethyl-4,4'-bipyridinium) \\
\hline $\mathrm{PVS}^{0}$ & propyl viologen sulfonate \\
\hline $\mathrm{PSS} / \mathrm{Ru}$ & $\begin{array}{l}\text { ratio of PSS repeat unit concentration to } \\
{\left[\mathrm{Ru}(\mathrm{bpy})_{3}\right]^{2+} \text { concentration }}\end{array}$ \\
\hline ssDNA & single-stranded DNA \\
\hline dsDNA & double-stranded DNA \\
\hline
\end{tabular}

\section{Acknowledgements}

The authors gratefully acknowledge support from EPSRC (GR/523315/01), Newcastle University (EPSRC impact funds) and COST D 35 for funding and networking opportunities that made this work possible.

\section{Notes and references}

1 Photochemistry and Photophysics of Polymer Materials, ed. N. S. Allen, Wiley, 2010.

2 K. Kalyanasundaram, Photochemistry in Microheterogenous Systems, Academic Press, 1987.

3 T. Okubo and N. Ise, J. Am. Chem. Soc., 1973, 95, 4031-4036.

4 Physical Chemistry of Polyelectrolytes, ed. T. Radeva, Surfactant Science Series, Marcel Dekker, Inc, vol. 99, 2001.

5 G. M. Blackburn, M. J. Gait, D. Loakes and D. Williams, Nucleic Acids in Chemistry and Biology, Royal Society of Chemistry, 2006.

6 N. Borochov and H. Eisenberg, Macromolecules, 1984, 27, $1440-1445$.

7 K. Kassapidou, W. Jesse, M. E. Kuil, A. Lapp, S. Egelhaaf and J. R. C. van der Maarel, Macromolecules, 1997, 30, 2671-2684.

8 G. Orellana, A. Kirsch-De Mesmaeker, J. K. Barton and N. J. Turro, Photochem. Photobiol., 1991, 54, 499-509.

9 C. Turro, S. H. Bossmann, S. Niu, J. K. Barton and N. J. Turro, Inorg. Chim. Acta, 1996, 252, 333-338.

10 N. Chen, A. A. Zinchenko, Y. Yamazaki, Y. Yoshikawa, S. Murata and K. Yoshikawa, Soft Matter, 2010, 6, 2834-2841.

11 Charge Transfer in DNA: From Mechanism to Application, ed. H.-A. Wagenknecht, Wiley-VCH, 2005.

12 P. Fromherz and B. Rieger, J. Am. Chem. Soc., 1986, 108, $5361-5362$.

13 S. J. Atherton and P. C. Beaumont, J. Phys. Chem., 1987, 91, 3993-3997.

14 A. M. Brun and A. Harriman, J. Am. Chem. Soc., 1992, 114 $3656-3660$.

15 C. J. Murphy, M. R. Arkin, N. D. Ghatlia, S. Bossmann, N. J. Turro and J. K. Barton, Proc. Natl. Acad. Sci. U. S. A., 1994, 91, 5315-5319.

16 P. Lincoln, E. Tuite and B. Nordén, J. Am. Chem. Soc., 1997, 119, 1454-1455.

17 E. J. C. Olson, D. Hu, A. Hörmann and P. F. Barbara, J. Phys. Chem. B, 1997, 101, 299-303. 
18 E. Tuite, in Molecular and Supramolecular Photochemistry, ed. V. Ramamurthy and K. Schanze, Organic and Inorganic Photochemistry, Marcel Dekker, New York, 1998, vol. 2, pp. 55-74.

19 A. Juris, V. Balzani, F. Bariggalletti, S. Campagna, P. Belser and A. Von Zelewsky, Coord. Chem. Rev., 1988, 84, 85-263.

20 J. G. Vos and J. M. Kelly, Dalton Trans., 2006, 4869-4883.

21 S. Campagna, F. Puntoriero, F. Nastasi, G. Bergamini and V. Balzani, Top. Curr. Chem., 2007, 280, 117-214.

22 H. Ishida, S. Tobita, Y. Hasegawa, R. Katoh and K. Nozaki, Coord. Chem. Rev., 2010, 254, 2449-2458.

23 A. Jensen, F. Basolo and H. M. Newmann, J. Am. Chem. Soc., 1959, 81, 509-512.

24 Y. Kurimura, H. Yakota, K. Shigehara and E. Tsuchida, Bull. Chem. Soc. Jpn., 1982, 55, 55-58.

25 E. R. Alvarez-Roa, N. E. Prieto and C. R. Martin, Anal. Chem., 1984, 56, 1939-1944.

26 A. Slama-Schwok and J. Rabani, Macromolecules, 1988, 21, 764-768.

27 G. L. Duveneck, C. V. Kumar, N. J. Turro and J. K. Barton, J. Phys. Chem., 1988, 92, 2028-2032.

28 T. Miyashita, Y. Arito and M. Matsuda, Macromolecules, 1991, 24, 872-876.

29 J. W. Park, M.-H. Kim, S. H. Ko and Y. H. Paik, J. Phys. Chem., 1993, 97, 5424-5429.

30 C. R. Bock, T. J. Meyer and D. G. Whitten, J. Am. Chem. Soc., 1974, 96, 4710-4712.

31 P. M. S. Monk, The Viologens, Wiley-Blackwell, 1998.

32 J. N. Braddock and T. J. Meyer, J. Am. Chem. Soc., 1973, 95, 3158-3162.

33 The Chemistry of Ruthenium, ed. E. D. Seddon and K. R. Seddon and R. J. H. Clark, Elsevier, Amsterdam, 1984.

34 T. Nagamura, T. Kurihara, T. Matsuo, M. Sumitani and K. Yoshihara, J. Phys. Chem., 1982, 86, 4368-4371.

35 H. Taguchi, N. Kunieda and M. Kinoshita, Makromol. Chem., 1983, 184, 925-933.

36 G. S. Anderson, R. C. Miller and A. R. H. Goodwin, J. Chem. Eng. Data, 2000, 45, 549-554.

37 P. M. Ennis and J. M. Kelly, J. Phys. Chem., 1989, 93, 5735-5740.

38 P. M. Ennis, J. M. Kelly and C. M. O'Connell, J. Chem. Soc., Dalton Trans., 1986, 2485-2491.

39 E. M. Kober, B. P. Sullivan and T. J. Meyer, Inorg. Chem., 1984, 23, 2098-2104.

40 A. W. McKinley, P. Lincoln and E. M. Tuite, Coord. Chem. Rev., 2011, 225, 2676-2692.

41 J. R. Lakowicz, Principles of Fluorescence Spectroscopy, Springer, 2nd edn, 1999.

42 J. V. Casper and T. J. Meyer, J. Am. Chem. Soc., 1983, 105, $5583-5590$.

43 R. E. Sassoon, S. Gershuni and J. Rabani, J. Phys. Chem., 1985, 89, 1937-1941.
44 E. Tuite, P. Lincoln and B. Norden, J. Am. Chem. Soc., 1997, 119, $239-240$

45 M. Montalti, A. Credi, L. Prodi and M. T. Gandolfi, Handbook of Photochemistry, CRC, 3rd edn, 2006.

46 I. B. Golovanov and S. M. Zhenodarova, Russ. J. Gen. Chem., 2005, 75, 1795-1797.

47 R. Battino, T. R. Rettich and T. Tominaga, J. Phys. Chem. Ref. Data, 1983, 12, 163-178.

48 N. J. Turro and T. Okubo, J. Am. Chem. Soc., 1982, 104, $2985-2988$.

49 S. Lapanje and S. Kovac, J. Macromol. Sci. (Chem.)., 1967, A1, 707-721.

50 J. Mattai and J. C. T. Kwak, Macromolecules, 1986, 19, $1663-1667$.

51 M. Drifford and J.-P. Dalbiez, J. Phys. Chem., 1984, 88, $5368-5375$.

52 L. Wang and H. Yu, Macromolecules, 1988, 21, 3498-3501.

53 G. Weill and G. Maret, Polymer, 1982, 23, 1990-1993.

54 M. Tricot, Macromolecules, 1984, 17, 1698-1704.

55 V. Degiorgio, F. Mantegazza and R. Piazza, Europhys. Lett., 1991, 15, 75-80.

56 N. N. Aylward, J. Polym. Sci., Polym. Chem. Ed., 1975, 13, 373-382.

57 J.-M. Y. Carrillo and A. V. Dobrynin, J. Phys. Chem. B, 2010, 114, 9391-9399.

58 T. Guarr, M. McGuire, S. Strauch and G. McLendon, J. Am. Chem. Soc., 1983, 105, 616-618.

59 T. Ohsako, T. Sakamoto and T. Matsuo, J. Phys. Chem., 1985, 89, 222-225.

60 I. Willner, J.-M. Yang, C. Laane, J. W. Otvos and M. Calvin, J. Phys. Chem., 1981, 85, 3277-3282.

61 I. Willner and W. E. Ford, J. Heterocycl. Chem., 1983, 20, $1113-1114$.

62 I. Willner and Y. Degani, J. Chem. Soc., Chem. Commun., 1982, 761-762.

63 K. Kalyanasundaram and M. Neumann-Spallart, Chem. Phys. Lett., $1982,88,7-12$.

64 J. M. Kelly, A. B. Tossi, D. J. McConnell and C. OhUigin, Nucleic Acids Res., 1985, 13, 6017-6034.

65 C. V. Kumar, J. K. Barton and N. J. Turro, J. Am. Chem. Soc., $1985, \mathbf{1 0 7}, 5518-5523$.

66 H. Gorner, A. B. Tossi, C. Stradowski and D. Schulte-Frohlinde, J. Photochem. Photobiol., B, 1988, 2, 67-89.

67 A. B. Tossi and J. M. Kelly, Photochem. Photobiol., 1989, 49, $545-556$.

68 A. E. Friedman, J.-C. Chambron, J.-P. Sauvage, N. J. Turro and J. K. Barton, J. Am. Chem. Soc., 1990, 112, 4960-4962.

69 C. Hiort, P. Lincoln and B. Nordén, J. Am. Chem. Soc., 1993, 115, 3448-3454.

70 J. C. Chambron and J. P. Sauvage, Chem. Phys. Lett., 1991, 182, 603-607. 